\title{
Short communication: Lactic acid bacteria from the honeybee inhibit the in vitro growth of mastitis pathogens
}

\author{
K. Piccart, ${ }^{* 1}$ A. Vásquez,† S. Piepers, ${ }^{*}$ S. De Vliegher, ${ }^{*}$ and T. C. Olofsson† \\ ${ }^{*}$ M-team \& Mastitis and Milk Quality Research Unit, Department of Reproduction, Obstetrics and Herd Health Faculty of Veterinary Medicine, \\ Ghent University, 9820 Merelbeke, Belgium \\ †Department of Laboratory Medicine Lund, Section of Medical Microbiology, Lund University, Building 404, Medicon Village, SE-223 81 Lund, \\ Sweden
}

\begin{abstract}
Despite the increasing knowledge of prevention and control strategies, bovine mastitis remains one of the most challenging diseases in the dairy industry. This study investigated the antimicrobial activity of 13 species of lactic acid bacteria (LAB), previously isolated from the honey crop of the honeybee, on several mastitis pathogens. The viable LAB were first reintroduced into a sterilized heather honey matrix. More than 20 different bovine mastitis isolates were tested against the mixture of the $13 \mathrm{LAB}$ species in the honey medium using a dual-culture overlay assay. The mastitis isolates were identified through bacteriological culturing, followed by matrix-assisted laser desorption/ionization time-of-flight mass spectrometry. Additionally, the mastitis isolates were subjected to antimicrobial susceptibility testing through disk diffusion. Growth of all tested mastitis pathogens, including the ones displaying antimicrobial resistance to one or more antimicrobial compounds, were inhibited to some extent by the honey and $\mathrm{LAB}$ combination. The antibacterial effect of these LAB opens up new perspectives on alternative treatment and prevention of bovine mastitis.
\end{abstract}

Key words: bovine mastitis, lactic acid bacteria, honey

\section{Short Communication}

Mastitis, an inflammation of the mammary gland, has a considerable negative effect on overall milk production (Lescourret and Coulon, 1994), milk quality (Schukken et al., 1992), animal welfare (Leslie and Petersson-Wolfe, 2012), and revenues of the farmer (Hogeveen et al., 2011). The majority of the bovine mastitis cases are attributed to staphylococci, streptococci, or coliform bacteria (Bradley, 2002). Despite

Received August 3, 2015.

Accepted December 8, 2015.

${ }^{1}$ Corresponding author: kristine.piccart@ugent.be various control and treatment strategies, mastitis remains a common concern for the global dairy industry. Mastitis is the predominant indication for antibiotic use in dairy cattle (De Briyne et al., 2014). Due to the risk of developing antimicrobial resistance (Chantziaras et al., 2014), alternative treatments and preventative measures are highly sought after.

Honey has been used therapeutically for centuries, and its antibacterial properties have been well documented (Molan, 1992a). Honey is also currently being used in veterinary medicine as a wound dressing (De Rooster and Declercq, 2008; Carnwath et al., 2014). The antibacterial mechanism behind honey has been attributed to its high osmolarity (Chirife et al., 1983), acidity (Bogdanov, 1997), and hydrogen peroxide production (White et al., 1963). Other antibacterial compounds include methylglyoxal [found especially in New Zealand Manuka honey (Mavric et al., 2008)] and bee defensin (Kwakman et al., 2010). However, recent research has identified a new source of antibacterial activity in fresh honey: a group of lactic acid bacteria (LAB) inhabiting the honey crop of various honeybee subspecies across the world (Apis mellifera ssp.; Olofsson and Vásquez, 2008; Vásquez et al., 2009; Olofsson et al., 2011). The recently discovered microbiota not only play an important role in the production of honey (Olofsson and Vásquez, 2008), but also protect the honeybee against different pathogens encountered in the hive and during nectar foraging (Vásquez et al., 2012). It has been demonstrated that 13 specific LAB species, comprising the genera Lactobacillus and Bifidobacterium, display an inhibitory effect on bee pathogens (Vásquez et al., 2012) and human wound pathogens (Butler et al., 2014). Every single LAB strain produces different compounds in different amounts. For instance, only 5 out of 13 strains are able to produce hydrogen peroxide (Olofsson et al., 2014). Even though all strains have the ability to form a biofilm under laboratory conditions, it is more pronounced in the bifidobacteria and Lactobacillus kullabergensis Biut2 (Olofsson et al., 2014). Also, certain LAB strains secrete a variety of proteins 
(such as bacteriocins and lyzozymes), whereas other strains (i.e., Bifidobacterium Bin7, Lactobacillus Hma8) produce little or no extracellular proteins (Butler et al., 2013). It is assumed that the LAB have evolved together to create a synergistic antimicrobial effect for the protection of the honeybees against a variety of microorganisms in pollen and nectar (Forsgren et al., 2010; Vásquez et al., 2012).

In this study, we evaluated the in vitro inhibitory effect of a mixture of the 13 well-known honeybee LAB species and phylotypes in Swedish heather honey on 27 bovine mastitis isolates. We tested the following honeybee LAB: Lactobacillus kunkeei Fhon2, Lactobacillus apinorum Fhon13, Lactobacillus mellis Hon2, Lactobacillus mellifer Bin4, Lactobacillus kullabergensis Biut2, Lactobacillus kimbladii Hma2, Lactobacillus helsingborgensis Bma5, Lactobacillus melliventris Hma8, Lactobacillus apis Hma11, Bifidobacterium coryneforme Bma6, Bifidobacterium asteroides Bin2, Bifidobacterium sp. Bin7, and Bifidobacterium sp. Hma3. The 13 previously isolated and identified LAB species were cultivated individually in a specialized pollen medium according to Vásquez and Olofsson (2012). A certain volume of the inoculated pollen medium, corresponding to approximately $2.0 \times 10^{8} \mathrm{cfu}$ of each species, was added to sterile (autoclaved) Swedish heather (Calluna vulgaris) honey, reaching a total count of $10^{9} \mathrm{cfu} / \mathrm{g}$. The honey itself acts as a prebiotic for the $13 \mathrm{LAB}$ species, enhancing their growth and their production of antimicrobial substances (Vásquez and Olofsson, 2012). The standardized honey mixture enriched with LAB was stored frozen $\left(-18^{\circ} \mathrm{C}\right)$ until further use.

Three reference strains and 25 field isolates associated with bovine mastitis were tested against the LAB mixture (Table 1). The field isolates were gathered over several years from dairy cows with mastitis (both clinical and subclinical) in the laboratory of the Mastitis and Milk Quality Research Unit at Ghent University. The milk samples were initially cultured by streaking $10 \mu \mathrm{L}$ on esculin blood and MacConkey agar (Oxoid, Basingstoke, UK), followed by overnight incubation at $37^{\circ} \mathrm{C}$. The culturing and identification was performed according to the guidelines of the National Mastitis Council (1999). Additionally, the identification of the isolates was confirmed with matrix-assisted laser desorption/ionization time-of-flight (MALDI-TOF) mass spectrometry (Butler et al., 2014). The isolates were stored in Microbanks (Pro-Lab Diagnostics, Austin, $\mathrm{TX})$ at $-80^{\circ} \mathrm{C}$ until further use.

The antimicrobial activity of the LAB was tested in a dual-overlay assay (Butler et al., 2014). Each mastitis pathogen was tested in duplicate. Blanc filter discs (Oxoid) were immersed in the heather honey mixture with LAB. In addition, all mastitis isolates were tested

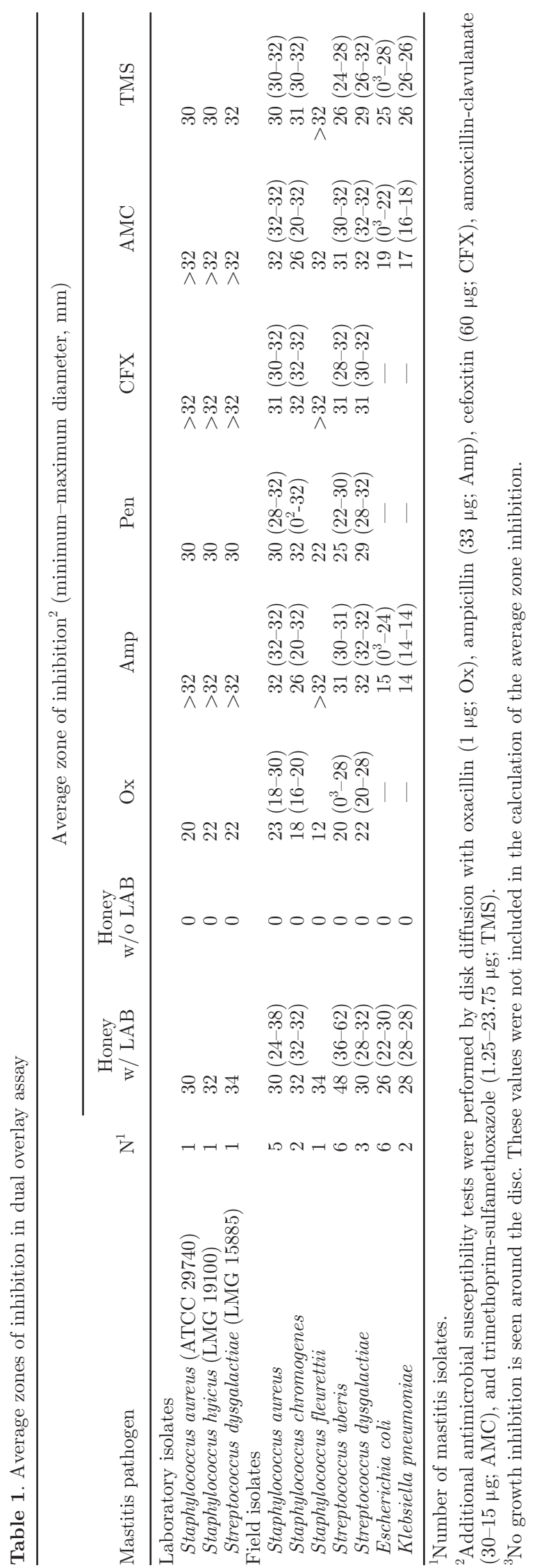

Journal of Dairy Science Vol. 99 No. 4, 2016 
in parallel against sterile honey (without LAB) as a negative control. Sterilization was achieved by autoclaving the honey at $102^{\circ} \mathrm{C}$ for $30 \mathrm{~min}$. Each disc was then placed in the center of a de Man, Rogosa, Sharpe agar plate (Oxoid) supplemented with fructose $(2 \%$, Merck, Sollentuna, Sweden) and L-cysteine (0.1\%, Sigma-Aldrich, Stockholm, Sweden). The plates were subsequently incubated anaerobically overnight at $35^{\circ} \mathrm{C}$. The mastitis isolates, having been stored in $\mathrm{Mi}-$ crobanks at $-80^{\circ} \mathrm{C}$ until that point, were cultured on blood agar plates (Oxoid) and incubated overnight at $37^{\circ} \mathrm{C}$. The following day, the mastitis pathogens were adjusted to $10^{8}$ cells $/ \mathrm{mL}$ (corresponding to an optical density between 0.5 and 0.6 at $540 \mathrm{~nm}$ ) in sterile water. A mixture was prepared by adding $500 \mu \mathrm{L}$ of the aforementioned pathogen solution to $10 \mathrm{~mL}$ of soft tryptic soy agar (TSA; $0.8 \%$; Oxoid) at $42^{\circ} \mathrm{C}$. The mixture was then gently poured as a top layer over the de Man, Rogosa, Sharpe plates with the honey-dipped discs.
The double-layer plates were incubated aerobically for approximately $24 \mathrm{~h}$ at $37^{\circ} \mathrm{C}$. Inhibition zone sizes of the mastitis pathogens were measured from the center of the disc to the sharp edge of the zone, and doubled for diameter.

Each mastitis isolate was subjected to additional antimicrobial susceptibility testing using the disk diffusion method (Supré et al., 2014). One colony was picked up from each isolate and adjusted to 0.5 McFarland in saline solution. Using a sterile swab, Mueller Hinton agar plates (bioMérieux, Paris, France) were streaked with the bacterial solution. The streptococci were streaked on Mueller Hinton plates supplemented with 5\% horse blood (bioMérieux). Antibiotic disks were applied with a dispenser. For the gram-positive bacteria, the following antibiotic disks were tested: ampicillin $(33 \mu \mathrm{g})$, oxacillin $(1 \mu \mathrm{g})$, cefoxitin $(60 \mu \mathrm{g})$, amoxicillin-clavulanate $(30-15 \mu \mathrm{g})$, and trimethoprimsulfamethoxazole $(1.25-23.75 \mu \mathrm{g})$. The gram-negative

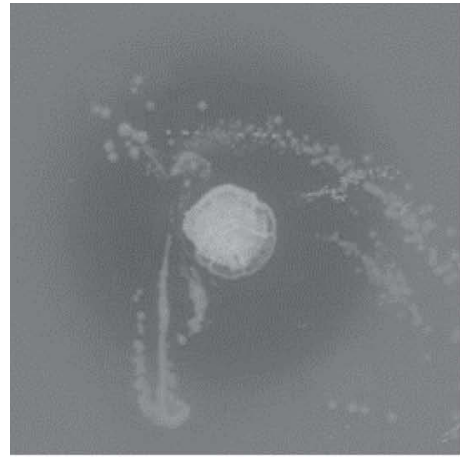

A

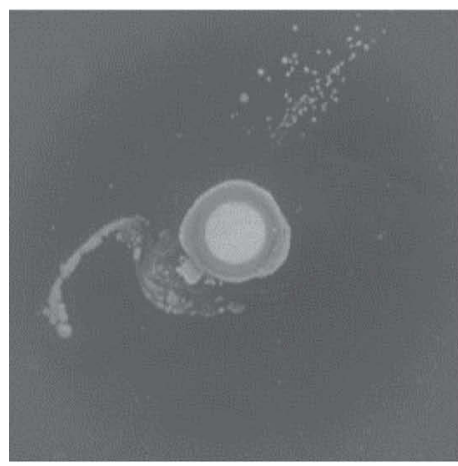

D

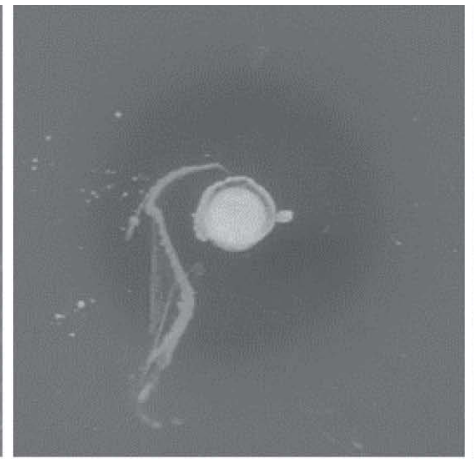

B

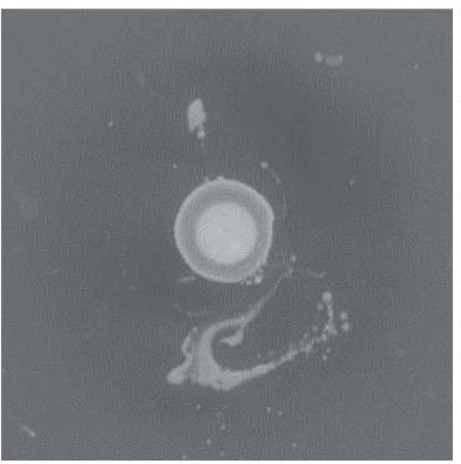

E

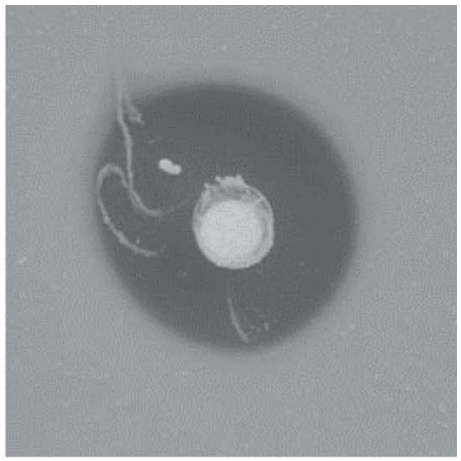

C

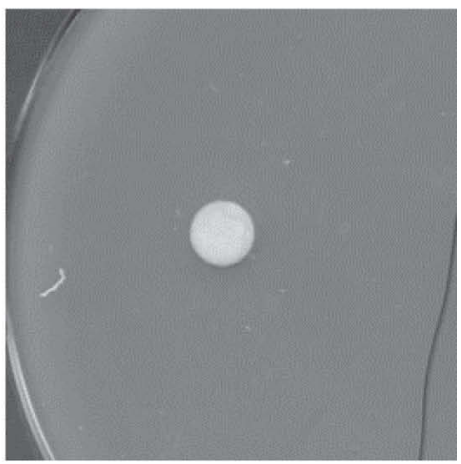

F

Figure 1. Dual overlay assay of honeybee lactic acid bacteria in heather honey with (A) Staphylococcus aureus Newbould 305; (B) Escherichia coli mastitis isolate; (C) Klebsiella pneumonia mastitis isolate; (D) Staphylococcus aureus mastitis isolate; and (E) Streptococcus dysgalactiae mastitis isolate. The final picture (F) depicts a negative control (i.e., honey without lactic acid bacteria) with a Staphylococcus aureus Newbould 305 (ATCC 29740) overlay; no inhibition zone is seen. 
bacteria were subjected to ampicillin, amoxicillinclavulanate, and trimethoprim-sulfamethoxazole.

The growth of every mastitis isolate was inhibited by the LAB and honey combination (Table 1). All isolates (both gram-negative and gram-positive) showed a clear, distinct inhibition pattern around the honeydipped disk with LAB (Figure 1). No inhibition zone was seen in the negative controls, indicating that the antibacterial effect can indeed be attributed to the LAB. Outside the inhibition zone, all mastitis isolates grew as a confluent lawn in the TSA layer, except for the Streptococcus uberis isolates. Without enriching the TSA with blood, only a faint growth of Strep. uberis was achieved. Nevertheless, an inhibition zone could still be distinguished around the honey-dipped disk with LAB.

Some mastitis isolates displayed a complete resistance to one or more antibiotic disks (i.e., no growth inhibition by the antibiotics). For instance, 4 out of 6 tested Strep. uberis isolates were resistant to oxacillin. In cases of Strep. uberis, oxacillin was added to the antimicrobial panel as an equivalent of cloxacillin, which is often used as intramammary mastitis therapy (Supré et al., 2014) or dry cow treatment (Sawant et al., 2005). Nevertheless, the 3 oxacillin-resistant isolates were inhibited by the honey and LAB combination. The same was observed in the 2 Escherichia coli isolates that were resistant to ampicillin and trimethoprim-sulfamethoxazole.

The present study indicates that the 13 LAB symbionts in the heather honey matrix have an inhibitory effect on all tested mastitis pathogens. Although the mechanism of action is not yet fully elucidated, previous research has identified multiple bioactive metabolites [such as free fatty acids, hydrogen peroxide, and organic acids that lower the $\mathrm{pH}$ of the environment (Olofsson et al., 2014)] and extracellular proteins (Butler et al., 2013) contributing to the antimicrobial activity. The sterilized heather honey itself showed no bacteriostatic effect, indicating that the LAB are mainly responsible for the observed antibacterial effect. This could explain why storage (Olofsson and Vásquez, 2008) and heat treatment (Molan, 1992b) tend to reduce the antibacterial activity of honey: the natural honeybee LAB microbiota are destroyed. In conclusion, the combination of the $13 \mathrm{LAB}$ in a heather honey matrix showed promising in vitro antibacterial activity against the tested mastitis pathogens.

\section{ACKNOWLEDGMENTS}

The authors express their appreciation for the excellent laboratory assistance of Éile Butler, Sepideh
Lamei, and Anette Mårtensson at the Department of Laboratory Medicine Lund, Section of Medical Microbiology of Lund University, and Anneleen De Visscher of the Mastitis and Milk Quality Research Unit at Ghent University.

\section{REFERENCES}

Bogdanov, S. 1997. Nature and origin of the antibacterial substances in honey. LWT Food Sci. Technol. 30:748-753.

Bradley, A. 2002. Bovine mastitis: An evolving disease. Vet. J. 164:116-128.

Butler, E., M. Alsterfjord, T. C. Olofsson, C. Karlsson, J. Malmstrom, and A. Vásquez. 2013. Proteins of novel lactic acid bacteria from Apis mellifera mellifera: An insight into the production of known extra-cellular proteins during microbial stress. BMC Microbiol. $13: 235-246$.

Butler, E., R. F. Oien, C. Lindholm, T. C. Olofsson, B. Nilson, and A. Vásquez. 2014. A pilot study investigating lactic acid bacterial symbionts from the honeybee in inhibiting human chronic wound pathogens. Int. Wound J. http://dx.doi.org/10.1111/iwj.12360.

Carnwath, R., E. M. Graham, K. Reynolds, and P. J. Pollock. 2014. The antimicrobial activity of honey against common equine wound bacterial isolates. Vet. J. 199:110-114.

Chantziaras, I., F. Boyen, B. Callens, and J. Dewulf. 2014. Correlation between veterinary antimicrobial use and antimicrobial resistance in food-producing animals: A report on seven countries. J. Antimicrob. Chemother. 69:827-834.

Chirife, J., L. Herszage, A. Joseph, and E. S. Kohn. 1983. In vitro study of bacterial growth inhibition in concentrated sugar solutions: Microbiological basis for the use of sugar in treating infected wounds. Antimicrob. Agents Chemother. 23:766-773.

De Briyne, N., J. Atkinson, L. Pokludova, and S. P. Borriello. 2014. Antibiotics used most commonly to treat animals in Europe. Vet. Rec. 175:325-333.

De Rooster, H., and I. Declercq. 2008. Honey for wound care: Myth or science? Part 2: Clinical cases with dogs. Flemish Veterinary Magazine 77:75-80.

Forsgren, E., T. C. Olofsson, A. Vásquez, and I. Fries. 2010. Novel lactic acid bacteria inhibiting Paenibacillus larvae in honey bee larvae. Apidologie (Celle) 41:99-108.

Hogeveen, H., K. Huijps, and T. J. G. M. Lam. 2011. Economic aspects of mastitis: New developments. N. Z. Vet. J. 59:16-23.

Kwakman, P. H., A. A. te Velde, L. de Boer, D. Speijer, C. M. Vandenbroucke-Grauls, and S. A. Zaat. 2010. How honey kills bacteria. FASEB J. 24:2576-2582.

Lescourret, F., and J. B. Coulon. 1994. Modeling the impact of mastitis on milk-production by dairy cows. J. Dairy Sci. 77:2289-2301.

Leslie, K. E., and C. S. Petersson-Wolfe. 2012. Assessment and management of pain in dairy cows with clinical mastitis. Vet. Clin. North Am. Food Anim. Pract. 28:289-305.

Mavric, E., S. Wittmann, G. Barth, and T. Henle. 2008. Identification and quantification of methylglyoxal as the dominant antibacterial constituent of Manuka (Leptospermum scoparium) honeys from New Zealand. Mol. Nutr. Food Res. 52:483-489.

Molan, P. C. 1992a. The antibacterial activity of honey: 1. The nature of the antibacterial activity. Bee World 73:5-28.

Molan, P. C. 1992b. The antibacterial activity of honey: 2. Variation in the potency of the antibacterial activity. Bee World 73:59-76.

National Mastitis Council. 1999. Laboratory Handbook on Bovine Mastitis. National Mastitis Council Inc., Madison, WI.

Olofsson, T. C., E. Butler, P. Markowicz, C. Lindholm, L. Larsson, and A. Vásquez. 2014. Lactic acid bacterial symbionts in honeybees-An unknown key to honey's antimicrobial and therapeutic activities. Int. Wound J. http://dx.doi.org/10.1111/iwj.12345.

Olofsson, T. C., and A. Vásquez. 2008. Detection and identification of a novel lactic acid bacterial flora within the honey stomach of the honeybee Apis mellifera. Curr. Microbiol. 57:356-363. 
Olofsson, T. C., A. Vásquez, D. Sammataro, and J. Macharia. 2011. A scientific note on the lactic acid bacterial flora within the honeybee subspecies Apis mellifera (Buckfast), A. m. scutellata, A. m. mellifera, and A. m. monticola. Apidologie (Celle) 42:696-699.

Sawant, A. A., L. M. Sordillo, and B. M. Jayarao. 2005. A survey on antibiotic usage in dairy herds in Pennsylvania. J. Dairy Sci. 88:2991-2999.

Schukken, Y. H., K. E. Leslie, A. J. Weersink, and S. W. Martin. 1992. Ontario bulk milk somatic cell count reduction program. 1. Impact on somatic-cell counts and milk quality. J. Dairy Sci. 75:3352-3358.

Supré, K., K. Lommelen, and L. De Meulemeester. 2014. Antimicrobial susceptibility and distribution of inhibition zone diameters of bovine mastitis pathogens in Flanders, Belgium. Vet. Microbiol. $171: 374-381$
Vásquez, A., E. Forsgren, I. Fries, R. J. Paxton, E. Flaberg, L. Szekely and T. C. Olofsson. 2012. Symbionts as major modulators of insect health: Lactic acid bacteria and honeybees. PLoS ONE 7:e33188.

Vásquez, A. and T.C. Olofsson. 2012. Method of modifying bacteria. Patent application, Sweden. ConCellae AB, Assignee. C12N 1/20, A23L 1/30, A61K 35/74, 2012.

Vásquez, A., T. C. Olofsson, and D. Sammataro. 2009. A scientific note on the lactic acid bacterial flora in honeybees in the USA - A comparison with bees from Sweden. Apidologie (Celle) 40:26-28.

White, J. W., Jr., M. H. Subers, and A. I. Schepartz. 1963. The identification of inhibine, the antibacterial factor in honey, as hydrogen peroxide and its origin in a honey glucose-oxidase system. Biochim. Biophys. Acta 73:57-70. 